\title{
COMPARISON OF STRUCTURE AND CHEMICAL COMPOSITION OF GROUND COVER AND SOILS OF FIR-SPRUCE FORESTS IN PECHORA-ILYCH STATE NATURE RESERVE, NORTHERN URALS
}

\author{
Irina Yu. Kudrevatykh", ${ }^{1, *}$, Anna P. Geraskina ${ }^{2}$ D \\ ${ }^{1}$ Institute of Physicochemical and Biological Problems of Soil Science of RAS, Russia \\ ${ }^{2}$ Center for Forest Ecology and Productivity of RAS, Russia \\ *e-mail: averkieva25@rambler.ru
}

Received: 23.07.2020. Revised: 30.03.2021. Accepted: 01.04.2021.

\begin{abstract}
Bilberry-feathermoss (BFM) fir-spruce forests on podzols and boreal tall herb (BTH) fir-spruce forests on brown soils were studied in the Pechora-Ilych State Nature Reserve, Northern Urals. In each type of forest, $50 \times 50-\mathrm{cm}^{2}$ monoliths were taken at the root zone depth $(n=54$ and $n=45$ for BTH and BFM, respectively). Living plants of herbs, dwarf shrubs, and mosses were taken from the monoliths for the subsequent determination of species and affiliation of the latter to functional groups. Profile pits with mixed sample selection from each soil horizon were also made in three replications on the same sites. Concentrations of $\mathrm{Mg}, \mathrm{Al}, \mathrm{P}, \mathrm{S}, \mathrm{K}, \mathrm{Ca}, \mathrm{Mn}, \mathrm{Fe}$, and $\mathrm{Zn}$ were measured in plant and soil samples using the X-ray fluorescence analysis. It was found that herbs form the bulk of the ground cover of the studied BTH fir-spruce forest. The boreal species proportion in the flora of these communities, if compared to that in the BFM flora, is $28 \%$ lower. On the contrary, the nemoral and nitrophilous species proportions are $20 \%$ and $14 \%$ higher, respectively. $\mathrm{Mg}, \mathrm{Zn}, \mathrm{Mn}$, and $\mathrm{Al}$ are accumulated in the shoots and roots of plants of both forest types, whereas the content of $\mathrm{Ca}, \mathrm{K}, \mathrm{S}$, and $\mathrm{P}$ is higher only in the roots. The chemical composition of plants is dependent on both their functional group and forest type they inhabit. The highest levels of $\mathrm{Ca}, \mathrm{K}, \mathrm{P}$, and $\mathrm{Mg}$ were found in boreal low herbs as well as in tall herbs in both forest types. The content of $\mathrm{Al}, \mathrm{Fe}, \mathrm{Zn}, \mathrm{Mn}$, and $\mathrm{S}$ was the highest in the BTH tall herbs. Boreal low herbs possess higher levels of K, S, $\mathrm{Mg}, \mathrm{P}, \mathrm{Zn}, \mathrm{Fe}$, and $\mathrm{Al}$ content in the BTH fir-spruce forest; the same is found for Mn content in boreal shrubs. The content of $\mathrm{P}, \mathrm{S}, \mathrm{Al}, \mathrm{Ca}, \mathrm{Fe}$, and $\mathrm{Mn}$ varies in meadow grasses of the fir-spruce forest, while tall herbs, both boreal and nemoral, display similar levels of $\mathrm{Al}, \mathrm{Fe}, \mathrm{Mn}$, and $\mathrm{Mg}$ content together with boreal low herbs. The comparison of soil ( $\mathrm{O}$ and A horizons) chemical composition in the forest types studied reveals that the content of $\mathrm{Ca}, \mathrm{Mg}, \mathrm{K}, \mathrm{Zn}, \mathrm{P}$, and $\mathrm{S}$ is $50 \%$ higher in brown soils, and the content of $\mathrm{Al}$ and $\mathrm{Fe}$ is higher in podzols. The latter fact originates mainly due to high amounts of the ground cover litter fall, rich in these elements.
\end{abstract}

Key words: bilberry-feathermoss forest, boreal tall-herb forest, Endogleyic Cambisol, plant functional group, Rustic Podzols

\section{Introduction}

The living forest cover plays an important role in biodiversity conservation, carbon storage, element cycling, and other major ecosystem functions (Ciccarese et al., 2012). Preserved natural forests, including those in the boreal zone and its northernboreal subzone, are of particular importance for the sustainability of these processes. The PechoraIlych State Nature Reserve (Northern Urals, Russia) forms one of the largest intact landscapes in Europe, widely known as UNESCO World Heritage site «Virgin forests of Komi Republic» (Degteva et al., 2015). The area of this Protected Area has been well-studied in terms of geology and mineralogy (Varsanofieva, 1940; Ilchukov, 2010), climate and air pollution (Bobretsov \& Teplov, 2000; Bobretsov et al., 2017; Vasilevich \& Simakin, 2017), history and culture (Bobrovsky \& Spai, 2017; Aleinikov, 2019). Currently, one of the main goals of scientific research in the Pechora-Ilych State Nature Reserve is that of the biodiversity assessment of natural ecosystems at different levels of their organisation. Hence a high level of study of forest associations and ground cover types (Lavrenko et al., 1995; Bobkova et al., 2010; Smirnov, 2013; Kanev et al., 2014; Seregin, 2014; Aleinikov et al., 2016; Shevchenko \& Smirnova, 2017) and soils (Semikolennykh et al., 2013; Degteva \& Lapteva, 2013; Zhangurov et al., 2019) is obtained there. Despite the high scientific interest, there are still a few data on chemical composition of the ground cover plants as well as on the variation of the latter in various forest associations and its influence on soil chemical composition. This fact determines the relevance of this study for the Pechora-Ilych State Nature Reserve area.

Natural and human-induced changes in boreal forest composition influence chemical cycles of elements. But predicting these effects requires a better understanding of the role of individual plant species in this processes (Van Cleve et al., 1991; Shorohova et al., 2009). Studies of chemical composition of forests usually focus on the $\mathrm{CO}_{2}$ balance (Lukac et 
al., 2010; Hilli, 2013; Nabuurs et al., 2013; Jurevics et al., 2016; Lehtonen \& Heikkinen, 2016), the cycles of nitrogen and phosphorus as major nutrient elements (Bäck et al., 1997; Finér et al., 2003; Cornelissen et al., 2007; Kreuzwieser \& Gessler, 2010; Novotný et al., 2016), or the plant and soil contamination with heavy metals (Sukhareva \& Lukina, 2014; Matveeva et al., 2019). Studies of behaviour of other macro- and microelements in the borealforest zone are mainly focused on trees (Artemkina et al., 2016; Matveeva et al., 2019; Robakidze et al., 2020), and only dominant species are studied in the field layer. In the meantime, it is the ground cover litter which is the main supplier of mineral nutrition elements to the soil due to rather small amounts of tree litter in dark-coniferous forests (Perevoznikova \& Baranchikov, 2002). Studies of correlations between the micro-element composition of field layer plants and soil are also of great research interest. Such research is relevant not only for the area of the Pechora-Ilych State Nature Reserve but also for our general understanding of the role of ground cover species in the cycles of macro- and micro-elements in boreal dark-coniferous forests.

This study is aimed to compare the field layer structure and chemical composition and the soil chemical composition in dark-coniferous forests of North-Eastern Europe, exemplified by the two firspruce stands, namely the boreal tall-herb and the bilberry-feathermoss ones. To accomplish this goal, the following tasks were performed: i) the assessment of differences in structure of the field layer in the boreal tall-herb and bilberry-feathermoss fir-spruce forests; ii) the comparison of chemical composition of plants of field and ground layers in the studied forest types; iii) the evaluation of differences in chemical composition of soil in the studied forest types; iv) finally, the evaluation of interdependence of the latter with the chemical composition of the field layer plants.

\section{Material and Methods}

The Pechora-Ilych State Nature Reserve, chosen as the study area, was established in 1930 to preserve the natural properties of forests in the Northern Urals (Fig. 1). The area is located within low- and mid-mountain tectonic denudation uplands with the predominance of acidic crystalline soil-forming maternal (Ilchukov, 2010). The regional climate is moderately continental, with an average annual temperature of $-0.4^{\circ} \mathrm{C}$ and an average annual precipitation of $627 \mathrm{~mm}$ (Bobretsov \& Teplov, 2000). The research objects are located in the foothill part of the Bolsheporozhny botanical-geographical region (Lavrenko et al., 1995). The vegetation cover is represented by dark-coniferous forests with the predominance of Picea obovata Ledeb., Abies sibirica Ledeb., and Pinus sibirica Du Tour. The study area is a part of the forest belt of the Ural Mountains, dominated by mountain-forest gley-podzolic humic-illuvial soils in its soil cover (Degteva \& Lapteva, 2013; Semikolennykh et al., 2013).

To estimate the chemical composition of field layer plants and its possible effect on soil chemical properties directly, we chose two contrasting species assemblages of the forest field and ground layers with the same species in the tree layer. Our field research was carried out in the bilberry-feathermoss fir-spruce forest (BFM; Piceeto-Abietum hylocomiosum) on podzolic soil (Rustic Podzol; WRB, 2006) and the boreal tall-herb fir-spruce forest (BTH, Piceeto-Abietum magnoherbosum) on brown soil (Endogleyic Cambisol; WRB, 2006). In each type of forest, $50 \times 50$ $\mathrm{cm}$ plots were laid with plot depth corresponding to root layer thickness $(\mathrm{n}=54$ and $\mathrm{n}=45$ for BTH and BFM, respectively) (Bazilevich et al., 1978). Living plants of herbs, dwarf-shrubs, and mosses were selected from each plot. Scientific names were unified according to the Plants of the World Online database (http://www.plantsoftheworldonline.org/). Functional groups were determined for each species. Based upon the functional response classification (Smirnova et al., 2017), the following vascular plant groups were identified: boreal dwarfshrubs and evergreen herbs ( $\left.\mathrm{Br} \_\mathrm{dw}\right)$, boreal low herbs $(\mathrm{Br} \mathrm{h})$, oligotrophic herbs $(\mathrm{Olg})$, nemoral tall herbs $\left(\mathrm{Nm}^{-}\right)$, boreal tall herbs $(\mathrm{Hh})$, nitrophilous herbs $(\mathrm{Nt})$, meadow herbs (Md). Shoots and roots of vascular plants were used for separate drying; mosses were dried as a whole. All plant specimens were placed on parchment paper; their surface impurities were removed with a stiff brush or wet cloth. Samples were then weighed according to a standard procedure and powdered when becoming air-dry for subsequent chemical and analytical studies (Kalra \& Maynard, 1991).

Profile pits were laid in triple replication in each forest type. Mixed soil samples, taken from each of the horizons, were cleaned of roots, large stones, and others in the laboratory. Purified samples were dried to a constant mass for $1-5 \mathrm{~h}$ in a drying cabinet depending on their granulometric composition, then placed into a desiccator with potassium chloride, and finally crushed to the particle size of $71 \mu \mathrm{m}$ in an agate mortar for the subsequent chemical analysis. The degree of grinding was evaluated by sieving. 


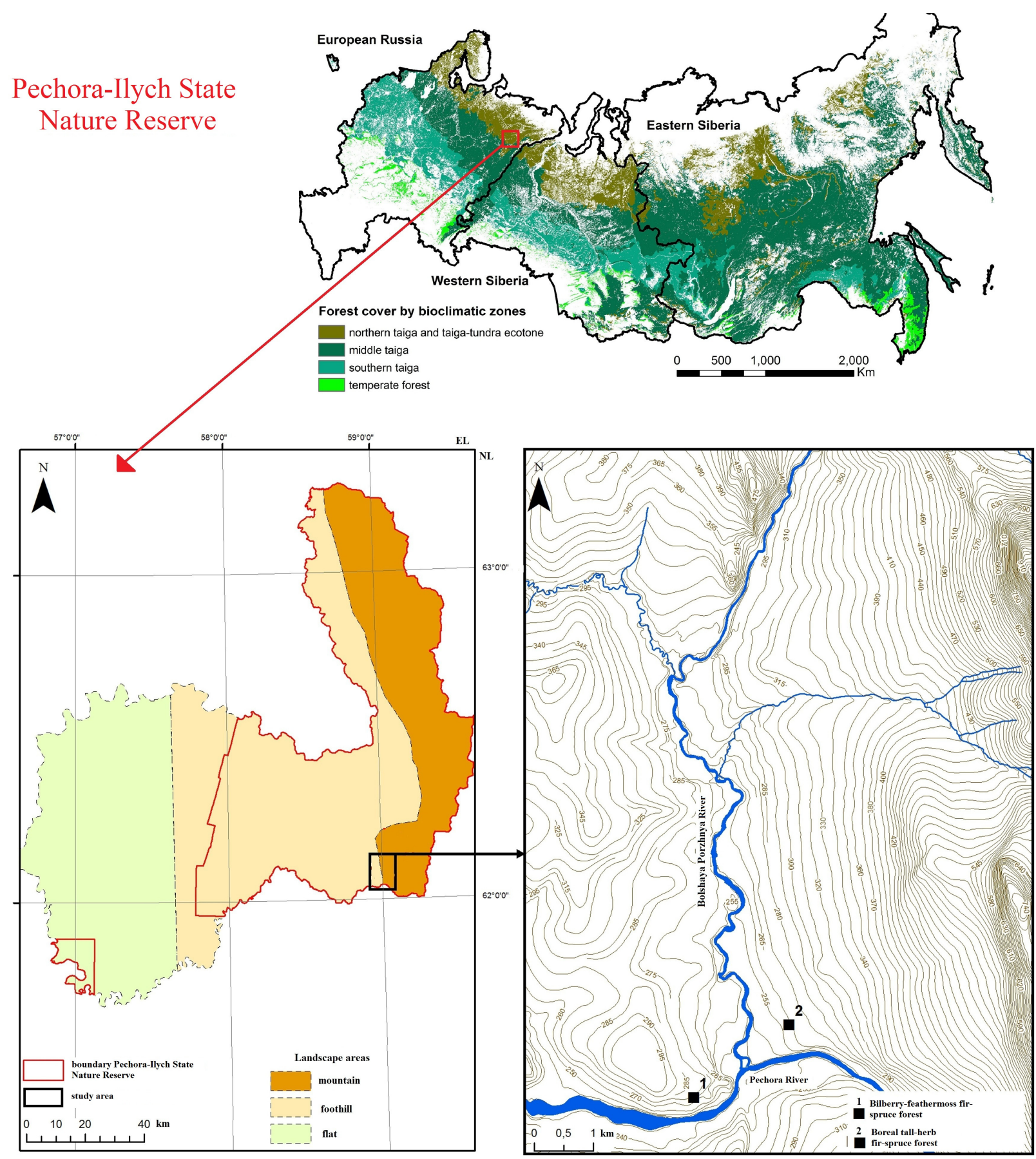

Fig. 1. Location of the study area and the Pechora-Ilych State Nature Reserve on the map of forest distribution across the bioclimatic zones (adapted from Loboda \& Chen, 2017).

Chemical analyses were performed at the laboratory of Geochemistry and Soil Mineralogy of the Institute of Physicochemical and Biological Problems of Soil Science of RAS (Pushchino, Russia). Concentrations of $\mathrm{Mg}, \mathrm{Al}, \mathrm{P}, \mathrm{S}, \mathrm{K}, \mathrm{Ca}$, $\mathrm{Mn}, \mathrm{Fe}$, and $\mathrm{Zn}$ in the obtained plant and soil samples were measured by means of the X-ray fluorescence analysis using a SPECTROSCAN MAX-GV desktop WD-XRF crystal-diffraction scanning spectrometer (Russia).

The phytomass and concentrations of chemical elements both in plants and the soil were determined in double replications. The results were documented as a mean value $(\ddot{x}) \pm$ standard error (SE). The experimental data compliance with the normal distribution was graphically evaluated on histograms and confirmed by the Shapiro-Wilk test. Multivariate analysis (analysis of the main components) and visualisation of the results as diagrams of chemical parameters for different study points were performed in the PC-ORD software environment. Comparing the chemical composition of different functional groups was carried out using the one-way analysis of variance and the Tukey posterior test. 


\section{Results}

Ground cover structure in studied forests

Piceeto-Abietum hylocomiosum is the dominant forest type in North-Eastern Europe and in the Pechora-Ilych State Nature Reserve, including the study area as well. Its stands cover the middle and lower parts of slopes. The field layer of these forests demonstrates a gradual transition from plant communities dominated by boreal dwarf-shrubs ( $\mathrm{Vac}$ cinium vitis-idaea L., V. myrtillus L.) to those with an equal representation of species from the boreal dwarf-shrubs and the boreal low herb groups $(O x$ alis acetosella L., Goodyera repens (L.) R.Br., Trientalis europaea L.). Pleurozium schreberi (Willd. ex Brid.) Mitt. is the most abundant epigeic moss. A typical feature of the moss layer of these forests is that of the co-dominance of Brachythecium spp. and Dicranum spp. on soil, which is uncommon in plant communities of other forest types in this area.

Piceeto-Abietum magnoherbosum was also found in the lower and middle parts of slopes in the study area. The field layer of this forest type is dominated by boreal tall herbs and grasses like Aconitum septentrionale Koelle, Calamagrostis arundinacea (L.) Roth., and Paeonia anomala L., whereas boreal low herbs (Gymnocarpium dryopteris (L.) Newm.) and dwarf-shrubs (Vaccinium myrtillus) grow under their cover, while Chrysosplenium serreanum Hand.-Mazz., Oxalis acetosella, and Adoxa moschatellina L. are found close to the soil surface. The ground layer is represented by boreal mosses (Pleurozium schreberi, Hylocomium splendens (Hedw.) Schimp., and Brachythecium spp.). However, the total moss cover is insignificant, and moss synusiae are confined mainly to fallen logs at the initial stages of their decomposition.

The ground cover of the studied boreal tall-herb fir-spruce forest comprises a wider set of functional groups ( $\mathrm{Br} \_\mathrm{dw}, \mathrm{Br} \mathrm{h}, \mathrm{Hh}, \mathrm{Md}$, and $\mathrm{Nm}$ groups) as compared to that of the bilberry-feathermoss forest ( $\mathrm{Br} d w, B r h$, and $\mathrm{Olg}$ ). The presence of nitrophilous and meadow-edge species in the BTH forest ground cover is typical for nutrient-rich soils. A comparison of the lists of vascular plant species of the studied forest types reveals that herbs compose the bulk of the BTH field layer. In addition, the BTH vascular flora has an $28 \%$ lower proportion of boreal species, as compared to the BFM flora. On the contrary, the proportion of nemoral and nitrophilous species is $20 \%$ and $14 \%$ higher in the latter flora, respectively.
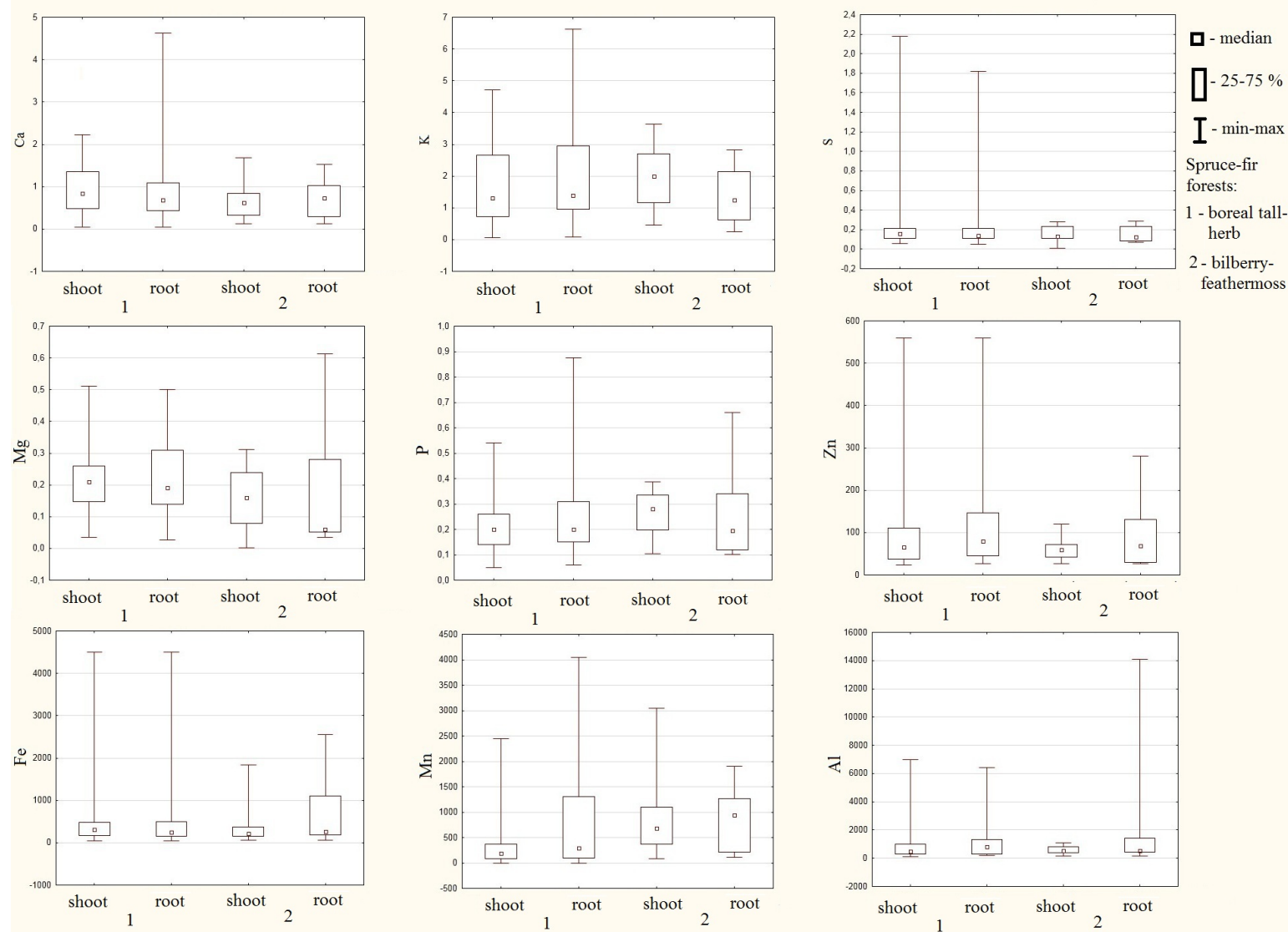

Fig. 2. Comparison of chemical composition of shoots and roots of vascular plants in the studied forest types in the PechoraIlych State Nature Reserve, Northern Urals. 
Phytomass and chemical composition of the studied plants

When comparing the chemical composition of vascular plants in the studied forest types, we discovered that tall-herb fir-spruce forest plants have higher $\mathrm{Ca}$ contents in their shoots and higher $\mathrm{K}$, $\mathrm{Mg}, \mathrm{P}, \mathrm{Zn}, \mathrm{Mn}$, and $\mathrm{Al}$ contents in the roots (Fig. 2). Bilberry-feathermoss fir-spruce forest plants have higher concentrations of $\mathrm{K}, \mathrm{S}$, and $\mathrm{P}$ in the shoots, and their roots contain more $\mathrm{Ca}, \mathrm{Mg}, \mathrm{Zn}$, $\mathrm{Fe}, \mathrm{Mn}$, and $\mathrm{Al}$ (Fig. 2). The content amplitude was higher in plants of the BTH forest for all the examined elements. It is worth noting that contents of all these elements, measured for $50 \%$ of the vascular flora species, do not differ significantly either between the shoots and roots of plants, or between the forest types studied (Fig. 2).

The air-dry phytomass of vascular plants and mosses is $140 \pm 28 \mathrm{~g}$ and $102 \pm 21 \mathrm{~g}$ for the studied monoliths from the BFM forest, respectively (Table 1). In this forest type, the highest concentrations of all the examined elements are found in the boreal low-herb group, with exception of Mn which displays its highest content in boreal dwarfshrubs (Vaccinium myrtillus, V. vitis-idaea, Linnaea borealis L.). The content of $\mathrm{Ca}$ in the BFM forest plants was the highest in Melampyrum sylvaticum L., Oxalis acetosella, and Chamaenerion angustifolium (L.) Scop., whereas the content of K and $\mathrm{S}$ was the highest in Equisetum sylvaticum L., Melampyrum sylvaticum, and Trientalis europaea. The contents of $\mathrm{Mg}$ and $\mathrm{P}$ were particularly high in Gymnocarpium dryopteris, Rubus arcticus L., and Goodyera repens as compared to other species of this forest type. The concentration of $\mathrm{Zn}$ in the roots of Gymnocarpium dryopteris, Melampyrum sylvaticum, and Oxalis acetosella was 200\% higher than the average value in all the other studied plants in this forest type, while the content of $\mathrm{Al}$ and $\mathrm{Fe}$ was extremely high in Equisetum sylvaticum, Goodyera repens, and again Gymnocarpium dryopteris. The chemical composition of mosses as compared to that of vascular plants shows lower values for all the elements except Mn (Table 1).

The air-dry phytomass of vascular plants and mosses in the BTH forest is $1405 \pm 65 \mathrm{~g}$ and $30 \pm 21$ g, respectively (Table 2). The chemical composition of plants in this forest type shows a stronger variation if compared to that in the BFM forest (Table 2). The Ca content in the BTH forest plants is the highest in plants of various functional groups, namely Geranium sylvaticum L., Rubus idaeus L., Solidago virgaurea L., and
Linnaea borealis. The highest $\mathrm{K}$ content is found in the representatives of the tall-herb group (Angelica sylvestris L., Delphinium elatum L., Diplazium sibiricum (Turcz. ex Kunze) Kurata). The concentration of S was $1000 \%$ higher in Stellaria nemorum L., Thalictrum minus L. s.1., Trientalis europaea, and Dryopteris phegopteris (L.) C.Chr. if compared to other species growing in this forest type. The $\mathrm{Mg}$ content varies within $0.2 \%$ and is the highest in Viola biflora L., Diplazium sibiricum, and Maianthemum bifolium (L.) F.W.Schmidt.

In the BTH forest plants, the $\mathrm{P}$ content is higher than that in those from the feathermoss forest. Its highest values are found in Stellaria nemorum and Vaccinium myrtillus. In Viola biflora and Pyrola minor L., the Fe content is 200\% higher than the average value for all the other plants in this forest type. The highest values of $\mathrm{Zn}$ are found in tall-herb and meadow-edge species, namely Angelica sylvestris, Vicia sepium L., Geranium sylvaticum, and Calamagrostis canadensis (Michx.) P.Beauv. The content of Mn displays a very large variation $(0.23-4.044 \mathrm{mg} /$ $\mathrm{kg}$ ) in the ground cover plants of this type of forest; its highest values are found in Vicia sepium and Dryopteris phegopteris. The Al content also shows a wide range of values, and its highest concentration is found in Vaccinium myrtillus, Equisetum sylvaticum, and Viola biflora. The chemical composition of mosses, if compared to that of vascular plants, displays lower proportions of all the examined elements.

According to the Tukey range test, no significant differences in contents of elements are found in plants of the examined functional groups (Table 1, Table 2). However, boreal low herbs of the bilberry-feathermoss forest display a higher variability of contents of $\mathrm{K}, \mathrm{S}, \mathrm{Mg}, \mathrm{P}, \mathrm{Zn}, \mathrm{Fe}$, and $\mathrm{Al}$ if compared to other functional groups, while boreal dwarf-shrubs display the same for the content of Mn. In the tall-herb forest, meadow herbs demonstrate the highest variability of contents of $\mathrm{P}, \mathrm{S}, \mathrm{Al}, \mathrm{Ca}, \mathrm{Fe}$, and $\mathrm{Mn}$. The content of $\mathrm{Al}, \mathrm{Fe}$, $\mathrm{Mn}$, and $\mathrm{Mg}$ is found to be nearly equal in boreal and nemoral tall herbs and boreal low herbs in the latter forest type. In the meantime, the results of comparing the contents of chemical elements in plants of the same functional groups $(\mathrm{Br} d \mathrm{dw}$ and $\mathrm{Br} \mathrm{h}$ ) in various forest types shows that the tall-herb forest plants accumulate higher proportions of elements if compared to those from the feathermoss forest. 
Table 1. Phytomass and elemental content of vascular plants and mosses in the bilberry-feathermoss spruce-fir forest in the Pechora-Ilych State Nature Reserve, Northern Urals

\begin{tabular}{|c|c|c|c|c|c|c|c|c|c|c|c|}
\hline \multirow{2}{*}{ Species } & \multicolumn{2}{|c|}{ Phytomass } & $\mathrm{Ca}$ & $\mathrm{K}$ & $\mathrm{S}$ & $\mathrm{Mg}$ & $\mathrm{P}$ & $\mathrm{Zn}$ & $\mathrm{Fe}$ & $\mathrm{Mn}$ & $\mathrm{Al}$ \\
\hline & \multicolumn{2}{|c|}{$\mathrm{g}$} & \multicolumn{5}{|c|}{$\%$} & \multicolumn{4}{|c|}{$\mathrm{mg} / \mathrm{kg}$} \\
\hline \multicolumn{12}{|l|}{$\mathrm{Br} \mathrm{h}$ - boreal low herbs } \\
\hline \multirow{2}{*}{ Linnaea borealis, Vaccinium myrtillus, Vaccinium vitis-idaea } & $\ddot{\mathrm{x}}$ & 17.8 & 0.62 & 0.76 & 0.09 & 0.05 & 0.14 & 40 & 183 & 1640 & 448 \\
\hline & SE & 16.9 & 0.25 & 0.48 & 0.01 & 0.04 & 0.04 & 13 & 108 & 402 & 269 \\
\hline \multicolumn{12}{|c|}{ Br_h - boreal low herbs } \\
\hline \multirow{2}{*}{$\begin{array}{l}\text { Chamaenerion angustifolium, Equisetum sylvaticum, Goodyera repens, Gymnocar- } \\
\text { pium dryopteris, Lycopodium annotinum L., Melampyrum sylvaticum, Orthilia se- } \\
\text { cunda (L.) House, Oxalis acetosella, Rubus arcticus, Trientalis europaea }\end{array}$} & $\ddot{\mathrm{x}}$ & 0.7 & 0.83 & 2.02 & 0.19 & 0.21 & 0.31 & 75 & 339 & 599 & 917 \\
\hline & SE & 0.6 & 0.35 & 0.67 & 0.06 & 0.12 & 0.08 & 39 & 248 & 407 & 616 \\
\hline \multicolumn{12}{|c|}{ Olg - oligotrophic herbs, $\mathrm{Nm}$ - nemoral tall herbs } \\
\hline \multirow{2}{*}{ Melica nutans L., Avenella flexuosa (L.) Drejer } & $\ddot{\mathrm{x}}$ & 0.6 & 0.19 & 1.81 & 0.08 & 0.06 & 0.23 & 51 & 179 & 402 & 454 \\
\hline & SE & 0.4 & 0.09 & 0.70 & 0.06 & 0.04 & 0.08 & 16 & 25 & 213 & 164 \\
\hline \multicolumn{12}{|l|}{ Mosses } \\
\hline \multirow{2}{*}{$\begin{array}{l}\text { Dicranum majus Turner, Dicranum polysetum Sw., Hylocomium splendens, Pleu- } \\
\text { rozium schreberi, Polytrichum commune Hedw., Ptilium crista-castrensis (Hedw.) } \\
\text { De Not. }\end{array}$} & $\ddot{\mathrm{x}}$ & 17.2 & 0.65 & 0.78 & 0.08 & 0.04 & 0.15 & \begin{tabular}{|l|}
54 \\
\end{tabular} & 259 & 771 & $40 \mathrm{~s}$ \\
\hline & SE & 14.4 & 0.11 & 0.06 & 0.02 & 0.01 & 0.01 & 9 & 79 & 256 & 116 \\
\hline
\end{tabular}

Note: $\ddot{\mathrm{x}}$ - mean value, $\mathrm{SE}$ - standard error of the mean.

Table 2. Phytomass and elemental content of vascular plants and mosses of the boreal tall-herb spruce-fir forest in the Pechora-Ilych State Nature Reserve, Northern Urals

\begin{tabular}{|c|c|c|c|c|c|c|c|c|c|c|c|}
\hline \multirow{2}{*}{ Species } & \multicolumn{2}{|c|}{ Phytomass } & $\mathrm{Ca}$ & $\mathrm{K}$ & $\mathrm{S}$ & $\mathrm{Mg}$ & $P$ & $\mathrm{Zn}$ & $\mathrm{Fe}$ & $\mathrm{Mn}$ & $\mathrm{Al}$ \\
\hline & \multicolumn{2}{|c|}{$\mathrm{g}$} & \multicolumn{5}{|c|}{$\%$} & \\
\hline \multicolumn{8}{|c|}{ Br_dw - boreal dwarf-shrubs } & \multicolumn{4}{|c|}{$\mathrm{mg} / \mathrm{kg}$} \\
\hline \multirow{2}{*}{$\begin{array}{l}\text { Linnaea borealis, Lycopodium annotinum, Orthilia secunda, } \\
\text { Dryopteris phegopteris, Pyrola minor, Vaccinium myrtillus, V. vitis- } \\
\text { idaea }\end{array}$} & $\ddot{\mathrm{x}}$ & 6.1 & 0.88 & 1.39 & 0.31 & 0.15 & 0.27 & 74 & 692 & 934 & 1756 \\
\hline & SE & 4.8 & 0.65 & 0.78 & 0.29 & 0.07 & 0.15 & 50 & 770 & 871 & 1682 \\
\hline \multicolumn{12}{|c|}{ Br_h - boreal low herbs } \\
\hline \multirow{2}{*}{$\begin{array}{l}\text { Adoxa moschatellina, Equisetum pratense Ehrh., Equisetum syl- } \\
\text { vaticum, Fragaria vesca L., Gymnocarpium dryopteris, Luzula pi- } \\
\text { losa } \text { (L.) Willd., Maianthemum bifolium, Melampyrum sylvaticum, } \\
\text { Milium effusum L., Oxalis acetosella, Ranunculus acris L., Stellaria } \\
\text { nemorum, Trientalis europaea, Viola biflora }\end{array}$} & $\ddot{\mathrm{x}}$ & 18.4 & 0.81 & 1.94 & 0.24 & 0.22 & 0.24 & 95 & 402 & 475 & 1460 \\
\hline & SE & 17.6 & 0.35 & 1.11 & 0.20 & 0.12 & 0.11 & 75 & 369 & 431 & 1627 \\
\hline \multicolumn{12}{|c|}{ Hh - boreal tall herbs } \\
\hline \multirow{2}{*}{$\begin{array}{l}\text { Aconitum septentrionale, Actaea erythrocarpa } \text { (Fisch.) Kom., Angelica } \\
\text { sylvestris, Clematis alpina subsp. sibirica } \text { (L.) Kuntze, Calamagrostis } \\
\text { arundinacea, Calamagrostis canadensis, Chamaenerion angustifo- } \\
\text { lium, Chrysosplenium serreanum, Crepis sibirica L., Delphinium ela- } \\
\text { tum, Geranium sylvaticum, Paeonia anomala, Rubus idaeus, Diplazi- } \\
\text { um sibiricum, Thalictrum minus, Valeriana rossica P.A.Smirn. }\end{array}$} & $\ddot{\mathrm{x}}$ & 11.9 & 0.87 & 1.73 & 0.28 & 0.16 & 0.20 & 109 & 304 & 448 & 1012 \\
\hline & SE & 13.6 & 0.51 & 1.30 & 0.20 & 0.10 & 0.09 & 95 & 274 & 455 & 942 \\
\hline \multicolumn{12}{|c|}{ Md - meadow herbs } \\
\hline \multirow{2}{*}{ Vicia sepium, Vicia sylvatica L., Dryopteris phegopteris } & $\ddot{\mathrm{x}}$ & 2.3 & 0.77 & 1.05 & 0.15 & 0.15 & 0.12 & 141 & 638 & 1007 & 2375 \\
\hline & SE & 2.0 & 0.61 & 0.85 & 0.06 & 0.09 & 0.03 & 127 & 556 & 983 & 1963 \\
\hline \multicolumn{12}{|c|}{$\mathrm{Nm}-$ nemoral tall herbs, $\mathrm{Nt}-$ nitrophilous tall herbs } \\
\hline \multirow{2}{*}{$\begin{array}{l}\text { Rubus saxatilis L., Galium boreale L., Lathyrus pratensis L., Lath- } \\
\text { yrus vernus (L.) Bernh., Melica nutans, Paris quadrifolia L., Soli- } \\
\text { dago virgaurea, Stellaria holostea L. }\end{array}$} & $\ddot{\mathrm{x}}$ & 29.0 & 1.06 & 2.21 & 0.20 & 0.23 & 0.28 & 85 & 278 & 363 & 1172 \\
\hline & SE & 38.4 & 0.53 & 1.05 & 0.11 & 0.08 & 0.07 & 52 & 162 & 268 & 914 \\
\hline \multicolumn{12}{|l|}{$\begin{array}{ll} & \\
& \\
\end{array}$} \\
\hline \multirow{2}{*}{$\begin{array}{l}\text { Dicranum majus, Hylocomium splendens, Pleurozium schreberi, } \\
\text { Polytrichum commune, Ptilium crista-castrensis, Rhodobryum rose- } \\
\text { um (Hedw.) Limpr., Rhytidiadelphus triquetrus (Hedw.) Warnst. }\end{array}$} & $\ddot{\mathrm{x}}$ & 4.4 & 0.60 & 1.63 & 0.13 & 0.12 & 0.22 & 75 & 641 & 402 & 1592 \\
\hline & SE & 3.6 & 0.39 & 0.72 & 0.05 & 0.07 & 0.09 & 24 & 594 & 191 & 1545 \\
\hline
\end{tabular}

Note: $\ddot{\mathrm{x}}$ - mean value, $\mathrm{SE}$ - standard error of the mean.

The multiple factor analysis of plant chemical composition shows that the BTH species display wider amplitudes of contents of all the studied elements in comparison with those from the BFM forest (Fig. 3). According to correlated elements accumulated by plants, the latter are divided into three groups. The group of species with high contents of $\mathrm{Ca}, \mathrm{K}$, $\mathrm{P}$, and $\mathrm{Mg}$ comprises the representatives of boreal low herbs and tall herbs in both forest types, and also in boreal dwarf-shrubs in the BTH forest. The group of species with high contents of $\mathrm{Al}, \mathrm{Fe}, \mathrm{Zn}$, and $\mathrm{Mn}$ includes only boreal tall-herb forest plants from various groups. Finally, the group of species with high contents of S is exclusively represented by tall herbs from the latter forest type. It was also shown that the BFM boreal low herbs contain the lowest levels of all the studied elements. 


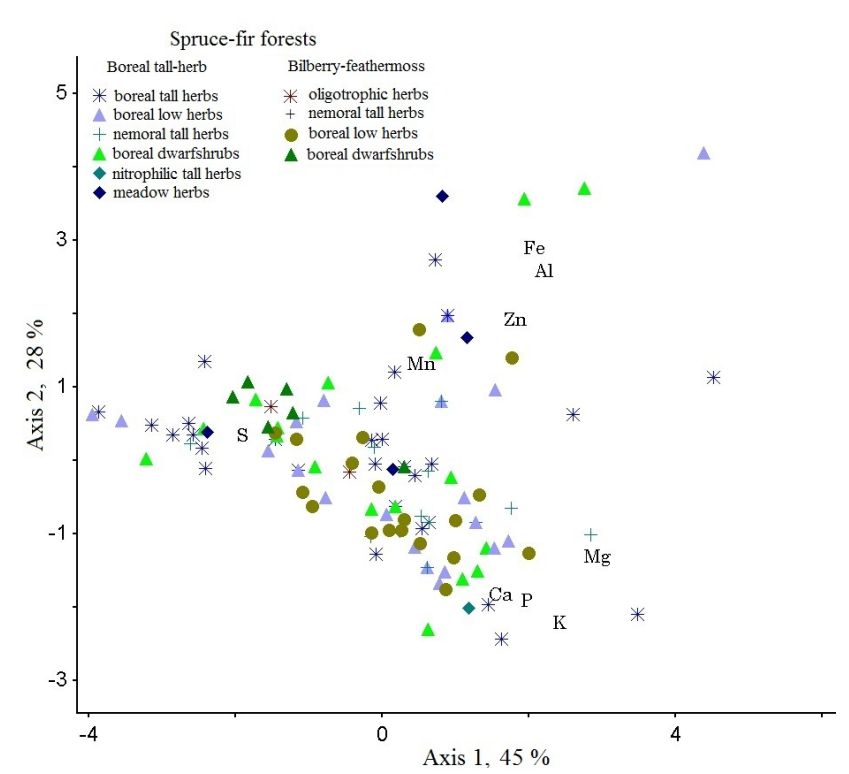

Fig. 3. Principal component analysis (PCA) of vascular plant elemental contents in the bilberry-feathermoss and boreal tall-herb fir-spruce forests in the Pechora-Ilych State Nature Reserve, Northern Urals.

\section{Chemical composition of soils}

Podzolic and brown soils were found under the bilberry-feathermoss and boreal tall-herb fir-spruce forests, respectively. $\mathrm{Ca}, \mathrm{Mg}, \mathrm{K}, \mathrm{Mn}, \mathrm{Zn}, \mathrm{P}$, and $\mathrm{S}$ are distributed accumulatively in soils of both forest types, whereas $\mathrm{Fe}$ and $\mathrm{Al}$ are subject to eluvial distribution (Table 3 ). When comparing the litter (horizon O) chemical composition of the studied forest types, it was found that the litter contents of $\mathrm{Ca}, \mathrm{Mg}, \mathrm{K}, \mathrm{Zn}$,
$\mathrm{P}$, and $\mathrm{S}$ are $50 \%$ higher in the brown soil, whereas those of $\mathrm{Al}$ and $\mathrm{Fe}$ are higher in the podzol. The profile 4 (brown soil in the BTH forest) is formed on a soil-forming maternal rock which is richer in $\mathrm{Ca}, \mathrm{K}$, and Mn (Table 3). To some extent, the latter fact determines higher proportions of these elements in the upper horizons of this soil type.

\section{Discussion}

The study reveals that the ground cover biodiversity differs greatly in the two compared forest types. The proportion of tall-herb, nemoral and nitrophilous species was higher in the BTH ground cover, whereas boreal species are most common in the BFM flora. Noteworthy, the ground cover biodiversity affects ecosystem functioning through two different mechanisms (Karpov, 1983; Gaston, 2010; Cardinale et al., 2012; Cadotte, 2013). One of them, known as the additive effect, is associated with niche division and facilitation, i.e. an increase in species diversity also increases the efficiency of resource utilisation and nutrient retention. The other mechanism, known as the choice effect, increases the likelihood of dominance of more productive species in a plant community. Our study has shown that the BTH forest demonstrates the additive effect, predetermined by a wider set of species and, accordingly, by an increased absorption and accumulation of elements as compared to that in a typical BFM forest.

Table 3. Chemical composition of studied soils in the Pechora-Ilych State Nature Reserve, Northern Urals

\begin{tabular}{|c|c|c|c|c|c|c|c|c|c|c|c|}
\hline \multirow{2}{*}{ Profile } & \multirow{2}{*}{$\begin{array}{l}\text { Soil } \\
\text { type }\end{array}$} & \multirow{2}{*}{ Horizon } & \multicolumn{9}{|c|}{ Content, $\mathrm{mg} / \mathrm{kg}$} \\
\hline & & & $\mathrm{Ca}$ & $\mathrm{Mg}$ & $\mathrm{K}$ & $\mathrm{Al}$ & $\mathrm{Fe}$ & $\mathrm{Mn}$ & $\mathrm{Zn}$ & $P$ & $\mathrm{~S}$ \\
\hline \multicolumn{12}{|c|}{ Bilberry-feathermoss spruce-fir forest } \\
\hline \multirow{3}{*}{1} & \multirow{3}{*}{ 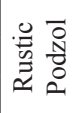 } & $\mathrm{O}$ & 1807 & 520 & 1141 & 39 & 7 & 541 & 47 & 285 & 179 \\
\hline & & $\mathrm{E}$ & 68 & 11 & 13 & 573 & 172 & 1 & 1 & 3 & 12 \\
\hline & & $\mathrm{Bf}$ & 109 & 16 & 18 & 993 & 2800 & 10 & 2 & 10 & 91 \\
\hline \multirow{3}{*}{2} & \multirow{3}{*}{ 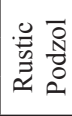 } & $\mathrm{O}$ & 3879 & 599 & 1569 & 139 & 8 & 707 & 45 & 298 & 154 \\
\hline & & E & 240 & 70 & 101 & 626 & 210 & 21 & 3 & 3 & 13 \\
\hline & & $\mathrm{BC}$ & 159 & 47 & 86 & 759 & 192 & 21 & 3 & 3 & 13 \\
\hline \multirow{4}{*}{3} & \multirow{4}{*}{ 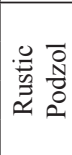 } & $\mathrm{O}$ & 7812 & 335 & 750 & 73 & 7 & 705 & 39 & 159 & 75 \\
\hline & & $E$ & 2013 & 88 & 116 & 324 & 128 & 219 & 5 & 10 & 18 \\
\hline & & B & 911 & 45 & 51 & 508 & 210 & 64 & 3 & 5 & 10 \\
\hline & & $\mathrm{BC}$ & 922 & 48 & 63 & 489 & 126 & 15 & 1 & 6 & 3 \\
\hline \multicolumn{12}{|c|}{ Boreal tall-herb spruce-fir forest } \\
\hline \multirow{3}{*}{4} & \multirow{3}{*}{ 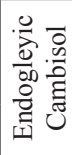 } & $\mathrm{O}$ & 14046 & 1057 & 1823 & 48 & 15 & 551 & 85 & 548 & 220 \\
\hline & & A & 5627 & 173 & 207 & 330 & 111 & 166 & 3 & 8 & 18 \\
\hline & & B & 8745 & 57 & 108 & 209 & 41 & 54 & 0 & 5 & 9 \\
\hline \multirow{3}{*}{5} & \multirow{3}{*}{ 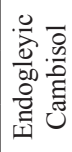 } & $\mathrm{O}$ & 7704 & 557 & 1090 & 79 & 8 & 970 & 61 & 230 & 97 \\
\hline & & A & 2349 & 163 & 161 & 394 & 88 & 408 & 9 & 9 & 19 \\
\hline & & $\mathrm{BC}$ & 597 & 56 & 92 & 866 & 265 & 58 & 2 & 5 & 15 \\
\hline \multirow{3}{*}{6} & \multirow{3}{*}{ 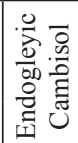 } & $\mathrm{O}$ & 7647 & 1052 & 1835 & 55 & 10 & 568 & 54 & 234 & 146 \\
\hline & & A & 1341 & 115 & 145 & 566 & 183 & 126 & 4 & 4 & 25 \\
\hline & & $\mathrm{BC}$ & 644 & 67 & 82 & 592 & 304 & 22 & 1 & 3 & 16 \\
\hline
\end{tabular}


Plant growth and development, including the absorption and migration of macro- and microelements, depend on various factors, the most important among them are temperature and light (Ksenzhek \& Volkov, 1998; Suh et al., 2000). Previous studies of fir-spruce forests in the PechoraIlych State Nature Reserve demonstrated that tree size and extent of root system development are significantly less in BFM than in BTH fir-spruce forests (Lugovaya et al., 2013; Shevchenko \& Smirnova, 2017). Due to this fact, it is assumed that a tree fall is not accompanied by an inversion of the large soil lump in the BFM forests. Therefore, no well-defined mounds and pits with better regimes of illumination, air drainage and soil warming are being formed. This effect is likely to determine the decline in biodiversity and plant biomass in the BFM forests. We believe that it should also be reflected as an increase in concentration of absorbed chemical elements in the BTH forest field layer plants.

Concentration of many elements, especially the micro-nutrients, is higher in plant roots than in above-ground plant parts (Cardwell et al., 2002; Shtangeeva et al., 2009). In particular, our results demonstrated that tall-herb forest plants display higher $\mathrm{Ca}$ contents in their aboveground parts and higher $\mathrm{K}, \mathrm{Mg}, \mathrm{P}, \mathrm{Zn}, \mathrm{Mn}$, and Al contents in the roots. The bilberry-feathermoss forest plants have higher concentrations of $\mathrm{K}, \mathrm{S}$, and $\mathrm{P}$ in their above-ground parts, and the roots contain more $\mathrm{Ca}, \mathrm{Mg}, \mathrm{Zn}, \mathrm{Fe}, \mathrm{Mn}$, and Al. Many studies reveal that nutrient and trace element concentrations in plants growing on the same substrata may be different in various plant species (Broadley et al., 2003; Fismes et al., 2005; Alexeeva-Popova \& Drozdova, 2013), which is associated with their genotype (Willey \& Fawcett, 2006). For example, concentrations of most of the macro- and micro-elements are considerably higher in the Poaceae roots than those in leaves, but those of $\mathrm{K}$ are lower. In the meantime, the concentrations of $\mathrm{Fe}$ and $\mathrm{K}$ are higher but those of $\mathrm{Ca}$ are lower in the Plantaginaceae leaves than in roots (Shtangeeva et al., 2009). A large proportion of these differences may be attributed to the phylogenetic division between monocots and dicots (Thompson et al., 1997; Broadley et al., 2003). Studies of chemical composition of the middle-boreal spruce forest ground cover demonstrated that the above-ground parts of dwarf-shrubs (Vaccinium myrtillus and $V$. vitis-idaea) and herbs display higher concentrations of all the ash elements compared to the roots (Likhanova \& Bobkova, 2013). It is also noted that the chemical composition of plants is depending upon their duration of growth. So, $\mathrm{Ca}, \mathrm{S}, \mathrm{Fe}$, and $\mathrm{Mn}$ are accumulated mainly in the perennial parts, while the mobile elements, like $\mathrm{P}$ and $\mathrm{K}$, are mainly concentrated in the young parts (Ilyin, 1985).

We showed that plants which concentrate chemical elements are different in various forest types studied. The highest contents of most chemical elements in the BFM forest are found in Melampyrum sylvaticum, Oxalis acetosella, Chamaenerion angustifolium, Equisetum sylvaticum, Trientalis europaea, Gymnocarpium dryopteris, and Goodyera repens. But in the BTH forests they are the highest in Geranium sylvaticum, Rubus idaeus, Solidago virgaurea, Linnaea borealis, Stellaria nemorum, Thalictrum minus, Trientalis europaea, Viola biflora, and Pyrola minor. Noteworthy, there are very few studies of chemical composition of the field layer of tall-herb fir-spruce forests, including the area of the Northern Urals. The most data collected in this region refer to the subject of chemical composition of ground cover and tree species in dwarf-shrub-feathermoss spruce or pine forests, most often measured when evaluating the response of plants to anthropogenic impact such as pollution, logging, wildfires and others (Shtangeeva et al., 2009; Likhanova \& Bobkova, 2013; Sukhareva \& Lukina, 2014; Baranovskaya \& Chernenkaya, 2015; Robakidze et al., 2020). The data on chemical composition of boreal dwarf-shrubs (Vaccinium myrtillus and $V$. vitis-idaea) in various forest types are best represented in these sources. According to these data, boreal forest species are considered Mn-concentrators. Our study shows that these species actually have the highest concentrations of $\mathrm{Mn}$ in the bilberry-feathermoss fir-spruce forest, but there are plants like Vicia sepium and Dryopteris phegopteris with higher contents of Mn (up to $4000 \mathrm{mg} / \mathrm{kg}$ ) in the tall-herb fir-spruce forest. A comparison of the accumulative capacity of representatives of various plant families in the Northern Urals shows that the low content of $\mathrm{Zn}$ and other trace elements is typical for the Poaceae, Cyperaceae, Empetraceae, and Ericaceae species, and the "habitual concentrators» of $\mathrm{Zn}$ are the Salicaceae and Betulaceae species (Alexeeva-Popova \& Drozdova, 2013). Mosses (Hilli, 2013) and lichens (Cornelissen et al., 
2007) are both characterised by a low content of nutrients and water-soluble extractives.

It was demonstrated that boreal low herbs in the BFM forest and meadow herbs in the BTH forest both display higher levels of variability in their contents of the majority of the studied elements, if compared to that in plants of other functional groups. It was also found that the contents of $\mathrm{Al}, \mathrm{Fe}, \mathrm{Mn}$, and $\mathrm{Mg}$ were relatively equal in tall-herb fir-spruce forest plants of the boreal tall-herb, boreal low-herb, and nemoral tall-herb groups. Similar results were obtained for the same functional groups of species in the northern-boreal and middle-boreal European Russia, where boreal tall and low herbs were discovered to be the closest groups in terms of their chemical composition (Khanina et al., 2015). It is indicated that these functional groups differ significantly in their characters from dark-conifer and light-conifer boreal dwarf-shrubs, the oligotrophic group species, and mosses which generally all have similar characters. Other studies of chemical composition of the ground cover of bilberry spruce forests and hairmoss-peatmoss spruce forests reveal that the concentrations of $\mathrm{Ca}, \mathrm{Mg}, \mathrm{Mn}$, and $\mathrm{Al}$ are higher in dwarf-shrubs, whereas those of $\mathrm{K}, \mathrm{P}$, and $\mathrm{Fe}$ are higher in herbs and that of $\mathrm{Mn}$ in dwarf-semi-shrubs (Likhanova \& Bobkova, 2013). Studies of chemical composition of the ground cover plants in bilberryfeathermoss pine forests and bilberry-peatmoss pine forests of the Republic of Komi (North European Russia) have also demonstrated that the content of $\mathrm{Al}, \mathrm{Ca}$, and $\mathrm{Mn}$ is higher in dwarfshrubs, while herbs have more Fe and $\mathrm{K}$ (Osipov et al., 2014). It was noted, too, that $\mathrm{Mn}$ and $\mathrm{Fe}$ are better accumulated in flowering plants in general, Fe also in nemoral species, and $\mathrm{Zn}$ in ferns (Sibgatullina \& Valiev, 2019).

Some studies also highlight the dependence of element accumulation by plants on properties of soil-forming rock (Kovda, 1985). The latter is represented by mostly acidic rock debris on the top of ridges under boreal tall-herb sprucefir forests in the study area. Eluvial and deluvial loam deposits can be found on slopes and foothills under bilberry-feathermoss fir-spruce forests (Degteva \& Lapteva, 2013). It is noted that plants growing on acidic rock have the highest Mn content, and those growing on ultrabasic rock have the highest content of Fe, while the $\mathrm{Zn}$ content does not correlate with the underlying bedrock composition (Alexeeva-Popova \&
Drozdova, 2010). Other studies of soils in the Pechora-Ilych State Nature Reserve demonstrated that formation of a well-developed field layer of ferns and tall herbs on brown soil may be attributed to carbonate rock proximity and the influence of the latter on physical and chemical soil properties (Degteva \& Lapteva, 2013).

The study of soil chemical composition shows that $\mathrm{Ca}, \mathrm{Mg}, \mathrm{K}, \mathrm{Mn}, \mathrm{Zn}, \mathrm{P}$, and $\mathrm{S}$ accumulate in the upper parts of soil profiles under both forest types, while $\mathrm{Fe}$ and $\mathrm{Al}$ accumulate in the lower parts of the latter. The eluvial distribution of $\mathrm{Fe}$ and $\mathrm{Al}$ in studied soils could be determined by many factors, e.g. climate humidity, abundance of vegetation cover which produces low-ash litter fall, ground-cover origin of the bulk of litter, good soil drainage, and leaching soil regime (Targulyan, 1971; Zaidel'man, 2007). In our opinion, the higher content of $\mathrm{Ca}, \mathrm{Mg}, \mathrm{K}, \mathrm{Zn}, \mathrm{P}$, and $\mathrm{S}$ in the $\mathrm{O}$ and $\mathrm{A}$ horizons of brown soil under the BTH forest depends, to a greater extent, on the litter fall of tall herbs, rich in chemical elements. Due to the small annual amount of woody debris in dark-coniferous forests compared to that in mixed or deciduous ones, the main part of mineral nutrition elements is supposed to come to the soil with the ground cover litter fall (Perevoznikova \& Baranchikov, 2002). Based upon correlations between the $\mathrm{Ca}, \mathrm{Mg}$, and $\mathrm{K}$ contents in soil organic horizons, it is also shown that herbs and grasses can promote the development of upper soil horizons of higher fertility better than dwarfshrubs, lichens, and mosses. The latter fact can be explained by differences in chemical composition of litter of different plant functional groups (Lukina et al., 2019). Phenol compounds in plant tissues (e.g. Ericaceae and Empetrum nigrum L.) prevent litter decomposition and therefore reduce concentrations of elements in the upper soil (Wardle et al., 2003; Li et al., 2007).

\section{Conclusions}

As a result of the study, we revealed that tallherb, nemoral and nitrophilous species prevail in the ground cover of boreal tall-herb fir-spruce forest, while the proportion of boreal species is higher in the bilberry-feathermoss fir-spruce forest flora. The analysis of chemical composition of plants shows that the highest content of the most of the studied elements is found in Melampyrum sylvaticum, Oxalis acetosella, Chamaenerion angustifolium, Equisetum sylvaticum, Trientalis europaea, Gymnocarpium dryopteris, and Good- 
yera repens in the bilberry-green moss fir-spruce forest. In the boreal tall-herb forest, the most active concentrators are Geranium sylvaticum, Rubus idaeus, Solidago virgaurea, Linnaea borealis, Stellaria nemorum, Thalictrum minus, Trientalis europaea, Viola biflora, and Pyrola minor.

A comparison of chemical composition of representatives of the studied flora shows that the accumulation of $\mathrm{Mg}, \mathrm{Zn}, \mathrm{Mn}$, and $\mathrm{Al}$ is higher in the root part of plants in both forest types. At the same time, the concentration of elements in the above-ground parts differs depending on the forest type. $\mathrm{Ca}$ is accumulated in boreal tall-herb forest plants instead of $\mathrm{K}, \mathrm{S}$, and $\mathrm{P}$ in those from the bilberry-feathermoss forests. The difference in chemical composition of the ground cover is determined by the $\mathrm{Ca}, \mathrm{K}, \mathrm{P}$, and $\mathrm{Mg}$ content variability in plants of both forest types, also the Al, $\mathrm{Fe}, \mathrm{Zn}, \mathrm{Mn}$, and $\mathrm{S}$ content variability in plants of the boreal tall-herb forest. When analysing the chemical composition of functional groups, it was shown that boreal low herbs display higher scatters of $\mathrm{K}, \mathrm{S}, \mathrm{Mg}, \mathrm{P}, \mathrm{Zn}, \mathrm{Fe}$, and $\mathrm{Al}$ content in the bilberry-feathermoss forest, while boreal dwarfshrubs possess a higher Mn content. Meadow herb group plants show the greatest variability in the contents of $\mathrm{P}, \mathrm{S}, \mathrm{Al}, \mathrm{Ca}, \mathrm{Fe}$, and $\mathrm{Mn}$ in the boreal tall-herb forest. In the meantime, the groups of boreal and nemoral tall herbs and boreal low herbs do not differ in their contents of $\mathrm{Al}, \mathrm{Fe}, \mathrm{Mn}$, and $\mathrm{Mg}$. A characteristic feature of the chemical composition of the boreal tall-herb forest soil is that of the increased contents of $\mathrm{Ca}, \mathrm{Mg}, \mathrm{K}, \mathrm{Zn}, \mathrm{P}$, and $\mathrm{S}$ in its upper horizons as compared to those under the bilberry-feathermoss forest.

The study also confirms that the ground cover of the boreal tall-herb forest is characterised by a higher level of floristic diversity in comparison to that of the bilberry-feathermoss forest. This phenomenon, in its turn, leads to an increase in absorption and accumulation of macro- and micro-elements by the ground cover plants and the enrichment of the upper soil horizons with $\mathrm{Ca}$, $\mathrm{Mg}, \mathrm{K}, \mathrm{Zn}, \mathrm{P}$, and $\mathrm{S}$.

\section{Acknowledgements}

The authors express their deep gratitude to Prof. Olga V. Smirnova (Center for Forest Ecology and Productivity of RAS, Russia) for the organising and conducting of the field work, valuable recommendations on research objects and comments on the interpretation of the obtained results. The work was supported by RFBR grant No. 19-04-00609A and within the framework of the state assignment No. 0191-2019-0048.

\section{References}

Aleinikov A.A. 2019. The fire history in pine forests of the plain area in the Pechora-Ilych Nature Biosphere Reserve (Russia) before 1942: possible anthropogenic causes and long-term effects. Nature Conservation Research 4(Suppl.1): 21-34. DOI: 10.24189/ncr.2019.033

Aleinikov A.A., Smirnov N.S., Smirnova O.V. 2016. Tall-herb boreal forests on North Ural. Russian Journal of Ecosystem Ecology 1(3). DOI: 10.21685/2500-0578-2016-3-3

Alexeeva-Popova N.V., Drozdova I.V. 2010. Specific Features of Mineral Composition of Plants Growing on Basic Rocks in Polar Urals. Botanicheskii Zhurnal 95(11): 1606-1622. [In Russian]

Alexeeva-Popova N.V., Drozdova I.V. 2013. Micronutrient composition of plants in the Polar Urals under contrasting geochemical conditions. Russian Journal of Ecology 44(2): 100-107. DOI: 10.1134/ S1067413613020033

Artemkina N.A., Orlova M.A., Lukina N.V. 2016. Chemical composition of Juniperus sibirica needles ( $\mathrm{Cu}$ pressaceae) in the forest-tundra ecotone, the Khibiny Mountains. Russian Journal of Ecology 47(4): 321328. DOI: 10.1134/S106741361604007X

Bäck J., Turunen M., Ferm A., Huttunen S. 1997. Needle Structures and Epiphytic Microflora of Scots Pine (Pinus sylvestris L.) under Heavy Ammonia Deposition from Fur Farming. Water, Air and Soil Pollution 100(1): 119-132. DOI: 10.1023/A:1018308008769

Baranovskaya N.V., Chernenkaya E.V. 2015. Features of accumulation of chemical elements in blueberries (Vaccinium myrtillus) in Western Siberia. Fundamental Research 2: 299-306. [In Russian]

Bazilevich N.I., Titlyanova A.A., Smirnov V.V., Rodin L.E., Nechayeva N.T., Levin F.I. 1978. Methods of studying biological cycle in various natural zones. Moscow: Mysl. 183 p. [In Russian]

Bobkova K.S., Robakidze E.A., Galenko E.P. 2010. Health status of the stands and the young growth in the native spruce forests at the Ural foothills, the upper reaches of the Pechora River. Contemporary Problems of Ecology 3(2): 196-202 DOI: 10.1134/S1995425510020098

Bobretsov A.V., Teplov V.V. 2000. Natural conditions of Pechora-Ilych Reserve. In: Patterns of half a century of biota dynamics in virgin taiga of Northern CisUrals. Syktyvkar. P. 6-21. [In Russian]

Bobretsov A.V., Tertitsa T.K., Teplova V.P. 2017. The impact of climate change on the phenology of plants and animals of the South-Eastern part of the Komi Republic (the Pechora-Ilych Biosphere Reserve). Problems of Environmental Monitoring and Ecosystem Modeling 28(4): 74-94. [In Russian]

Bobrovsky M.V., Spai T.P. 2017. History of fires in forests of the foothill area of Pechora-Ilych State Nature Reserve according to dendrochronological data In: Boreal forests: state, dynamics, ecosystem services. Petrozavodsk: Karelian Research Centre of RAS. P. 36-38. [In Russian] 
Broadley M.R., Bowen H.C., Cotterill H.L., Hammond J.P., Meacham M.C., Mead A., White P.J. 2003. Variation in the shoot calcium content of angiosperms. Journal of Experimental Botany 54(386): 1431-1446. DOI: $10.1093 / \mathrm{jxb} / \mathrm{erg} 143$

Cadotte M.W. 2013. Experimental evidence that evolutionarily diverse assemblages result in higher productivity. Proceedings of the National Academy of Sciences of the United States of America 110(22): 8996-9000. DOI: $10.1073 /$ pnas.1301685110

Cardinale B.J., Duffy J.E., Gonzales A., Hooper D.U., Perrings C., Venaill P., Narwani1 A., Mace G.M., Tilman D., Wardle D.A., Kinzig A.P., Daily G.C., Loreau M., Grace J.B., Larigauderie A., Srivastava D.S., Naeem S. 2012. Biodiversity loss and its impact on humanity. Nature 486: 59-67. DOI: 10.1038/nature11148

Cardwell A.J., Hawker D.W., Greenway M. 2002. Metal accumulation in aquatic macrophytes from southeast Queensland, Australia. Chemosphere 48(7): 653-663. DOI: 10.1016/S0045-6535(02)00164-9

Ciccarese L., Mattsson A., Pettenella D. 2012. Ecosystem services from forest restoration: thinking ahead. New Forests 43(5-6): 543-560. DOI: 10.1007/ s11056-012-9350-8

Cornelissen J.H., van Bodegom P.M., Aerts R., Callaghan T.V., van Logtestijn R.S., Alatalo J., Chapin F.S., Gerdol R., Gudmundsson J., Gwynn-Jones D., Hartley A.E., Hik D.S., Hofgaard A., Jynsdyttir I.S., Karlsson S., Klein J.A., Laundre J., Magnusson B., Michelsen A., Molau U., Onipchenko V.G., Quested H.M., Sandvik S.M., Schmidt I.K., Shaver G.R., Solheim B., Soudzilovskaia N.A., Stenström A., Tolvanen A., Totland Ø. et al. 2007. Global negative vegetation feedback to climate warming responses of leaf litter decomposition rates in cold biomes. Ecology Letters 10(7): 619-627. DOI: 10.1111/j.14610248.2007.01051.x

Degteva S.V., Lapteva E.M. (Eds.). 2013. Soils and soil cover of Pechora-Ilych State Nature Reserve (Northern Urals). Syktyvkar: IB Komi Science Center, UB RAS. 328 p. [In Russian]

Degteva S.V., Ponomarev V.I., Eisenman S.W., Dushenkov V. 2015. Striking the balance: Challenges and perspectives for the protected areas network in northeastern European Russia. Ambio 44(6): 473-490. DOI: 10.1007/s13280-015-0636-x

Finér L., Mannerkoski H., Piirainen S., Starr M. 2003. Carbon and nitrogen pools in an old-growth, Norway spruce mixed forest in eastern Finland and changes associated with clear-cutting. Forest Ecology and Management 174(1-3): 51-63. DOI: 10.1016/S03781127(02)00019-1

Fismes J., Echevarria G., Leclerc-Cessac E., Morel J.L. 2005. Uptake and Transport of Radioactive Nickel and Cadmium into Three Vegetables after Wet Aerial Contamination. Journal of Environmental Quality 34(5): 1497-1507. DOI: 10.2134/jeq2004.0274

Gaston K.J. 2010. Valuing common species. Science 327(5962): 154-155. DOI: 10.1126/science.1182818
Hilli S. 2013. Significance of litter production of forest stands and ground vegetation in the formation of organic matter and storage of carbon in boreal coniferous forests. In: P. Merilä, S. Jortikka (Eds.): Forest Condition Monitoring in Finland - National Report. Helsinki: The Finnish Forest Research Institute. Available from http://www.metla.fi/metinfo/forestcondition/intensive-monitoring/foliar-chemistry.htm

Ilchukov S.V. 2010. Landscapes of Pechora-Ilych Biosphere Reserve. Proceedings of the Pechora-Ilych State Nature Reserve 16: 68-83. [In Russian]

Ilyin B.V. 1985. Elemental chemical composition of plants. Novosibirsk: Nauka. 129 p. [In Russian]

Jurevics A., Peichl M., Olsson B.A., Strumgren M., Egnell G. 2016. Slash and stump harvest have no general impact on soil and tree biomass C pools after 32-39 years. Forest Ecology and Management 371: 33-41. DOI: $10.1016 /$ j.foreco.2016.01.008

Kalra Y.P., Maynard D.G. 1991. Methods manual for forest soil and plant analysis. Information Report NORX-319E. Alberta: Ministry of Supply and Services Canada. 116 p.

Kanev V.A., Degteva S.V., Poletaeva I.I. 2014. Flora of vascular plants of the Man-Hambo Ridge (Northern Urals, Pechora-Ilych State Nature Reserve). Proceedings of the Komi Science Centre of the Ural Division of the Russian Academy of Sciences 3(19): 75-82. [In Russian]

Khanina L.G., Bobrovsky M.V., Smirnov V.E., Grozovskaya I.S., Romanov M.S., Lukina N.V., Isaeva L.G. 2015. Ground Vegetation Modeling through Functional Species Groups and Patches in the Forest Floor. Mathematical Biology and Bioinformatics 10(1): 1533. DOI: 10.17537/2015.10.15 [In Russian]

Karpov V.G. 1983. Regulation factors of spruce forest ecosystems. Leningrad: Nauka. 317 p. [In Russian]

Kovda V.A. 1985. Biogeochemistry of Soil Cover. Moscow: Nauka. 264 p. [In Russian]

Kreuzwieser J., Gessler A. 2010. Global climate change and tree nutrition: influence of water availability. Tree Physiology 30(9): 1221-1234. DOI: 10.1093/ treephys/tpq055

Ksenzhek O., Volkov A. 1998. Plant Energetics. New York: Academic Press. 389 p.

Lavrenko A.N., Ulle Z.G., Serditov N.P. 1995. Flora of the Pechora-Ilych Biosphere Reserve. Saint Petersburg: Nauka. 256 p. [In Russian]

Lehtonen A., Heikkinen J. 2016. Uncertainty of upland soil carbon sink estimate for Finland. Canadian Journal of Forest Research 46(3): 310-322. DOI: 10.1139/ cjfr-2015-0171

Li X., Han S., Zhang Y. 2007. Indirect effects of precipitation variation on the decomposition process of Mongolian oak (Quercus mongolica) leaf litter. Frontiers of Forestry in China 2: 417-423. DOI: 10.1007/ s11461-007-0066-4

Likhanova N.V., Bobkova K.S. 2013. Alteration of macro and microelement content in the plants of ground cover vegetation in the middle taiga spruce forests 
after clear felling. Rastitelnye Resursy 49(2): 223 232. [In Russian]

Loboda T.V, Chen D. 2017. Spatial distribution of young forests and carbon fluxes within recent disturbances in Russia. Global Change Biology 23(1): 138-153. DOI: $10.1111 / \mathrm{gcb} .13349$

Lugovaya D.L., Smirnova O.V., Zaprudina M.V., Aleynikov A.A., Smirnov V.E. 2013. Micromosaic structure and phytomass of ground vegetation in main types of dark conifer forests in the Pechora-Ilych State Nature Reserve. Russian Journal of Ecology 44(1): 1-8. DOI: 10.1134/S1067413613010086

Lukac M., Calfapietra C., Lagomarsino A., Loreto F. 2010. Global climate change and tree nutrition: effects of elevated $\mathrm{CO}_{2}$ and temperature. Tree Physiology 30(9): 1209-1220. DOI: 10.1093/treephys/tpq040

Lukina N.V., Tikhonova E.V., Danilova M.A., Bakhmet O.V., Kryshen A.M., Tebenkova D.N., Kuznetsova A.I., Smirnov V.E., Braslavskaya T.Yu., Gornov A.V., Shashkov M.P., Knyazeva S.V., Kataev A.D., Isaeva L.G., Zukert N.V. 2019. Associations between forest vegetation and the fertility of soil organic horizons in northwestern Russia. Forest Ecosystems 6: 34. DOI: 10.1186/s40663-019-0190-2

Matveeva R.N., Bratilova N.P., Kubrina S.M., Shcherba Yu.E. 2019. Concentration of trace elements in seeds and needles of Siberian pine of various geographic origin. Russian Journal of Forest Science 6: 567-572. DOI: $10.1134 / \mathrm{S} 0024114819060056$

Nabuurs G., Lindner M., Verkerk P.J., Gunia K., Deda P., Michalak R., Grassi G. 2013. First signs of carbon sink saturation in European forest biomass. Nature Climate Change 3: 792-796. DOI: 10.1038/nclimate 1853

Novotný R., Buriánek V., Šrámek V., Hůnová I., Skořepová I., Zapletal M., Lomský B. 2016. Nitrogen deposition and its impact on forest ecosystems in the Czech Republic - change in soil chemistry and ground vegetation. iForest 10(1): 48-54. DOI: 10.3832/ifor1847-009

Osipov A.F., Manova S.O., Bobkova K.S. 2014. Reserves and element composition in ground cover plants in the pine forests of post-fire origin (the Komi Republic). Rastitelnye Resursy 50(1): 3-11. [In Russian]

Perevoznikova V.D., Baranchikov Yu.N. 2002. Structure of land phytomass stocks in fresh silkworms of fir taiga of the Lower Angara. In: Entomological Studies in Siberia. Vol. 2. Krasnoyarsk: KF SO REO. P. 166-180. [In Russian]

Robakidze E.A., Bobkova K.S., Naimushina S.I. 2020. Elemental composition of dominating plant species in different-aged middle-taiga pine forests of Komi Republic. Rastitelnye Resursy 56(1): 53-65. DOI: 10.31857/S0033994620010045 [In Russian]

Semikolennykh A.A., Bovkunov A.D., Aleinikov A.A. 2013. Soils and the soil cover of the taiga zone in the Northern Urals (upper reaches of the Pechora River). Eurasian Soil Science 46(8): 821-832. DOI: 10.1134/ S1064229313080085

Seregin A.P. 2014. Floristic records from Man-Pupu-Nyor Range and adjacent paths (Pechora-Ilych Reserve,
Komi Republic, Russia). Phytodiversity of Eastern Europe 8(2): 97-105. [In Russian]

Shevchenko N.E., Smirnova O.V. 2017. Refugia for the floristic diversity of Northern Ural dark conifer forests as markers of natural vegetation of the eastern European Taiga. Russian Journal of Ecology 48(3): 212-218. DOI: 10.1134/S1067413617030183

Shorohova E., Kuuluvainen T., Kangur A., Jõgiste K. 2009. Natural stand structures, disturbance regimes and successional dynamics in the Eurasian boreal forests: a review with special reference to Russian studies. Annals of Forest Science 66: 201. DOI: 10.1051/forest/2008083

Shtangeeva I., Alber D., Bukalis G., Stanik B., Zepezauer F. 2009. Multivariate statistical analysis of nutrients and trace elements in plants and soil from northwestern Russia. Plant and Soil 322(1): 219-228. DOI: 10.1007/s11104-009-9910-7

Sibgatullina M.Sh., Valiev V.S. 2019. Trace elements in wild plants of the Lower Kama National Park. Environment and Human: Ecological Studies 9(3): 325342. DOI: 10.31862/2500-2961-2019-9-3-325-342 [In Russian]

Smirnov N.S. 2013. Typological and species diversity of dark conifer forests in the lower reaches of the Bol'shaya Porozhnyaya River, a tributary of the Pechora (Pechora-Ilych State Nature Reserve). Russian Journal of Ecology 44(1): 28-35. DOI: 10.7868/ S0367059713010125

Smirnova O.V., Bobrovsky M.V., Khanina L.G., Zaugolnova L.B., Korotkov V.N., Aleinikov A.A., Evstigneev O.I., Smirnov V.E., Smirnov N.S., Zaprudina M.V. 2017. Boreal forests. In: European Russian forests. Their current state and features of their history. Netherlands: Springer. P. 59-203.

Suh S., Moran N., Lee Y. 2000. Blue Light Activates Potassium-Efflux Channels in Flexor Cells from Samanea saman Motor Organs via Two Mechanisms. Plant Physiology 123(3): 833-844. DOI: 10.1104/pp.123.3.833

Sukhareva T.A., Lukina N.V. 2014. Mineral composition of assimilative organs of conifers after reduction of atmospheric pollution in the Kola Peninsula. Russian Journal of Ecology 45(2): 95-102. DOI: 10.1134/ S1067413614020088

Targulyan V.O. 1971. Soil formation and weathering in cold humid areas. Moscow: Nauka. 268 p. [In Russian]

Thompson K., Parkinson J.A., Band S.R., Spencer R.E. 1997. A comparative study of leaf nutrient concentrations in a regional herbaceous flora. New Phytologist 136(4): 679-689. DOI: 10.1046/j.1469-8137.1997.00787.x

Van Cleve K., Chapin F.S., Dyrness C.T., Viereck L.A. 1991. Element Cycling in Taiga Forests: State-Factor Control: A framework for experimental studies of ecosystem processes. BioScience 41(2): 78-88. DOI: $10.2307 / 1311560$

Varsanofieva V.A. 1940. Geological structure of the territory of the Pechora-Ilych State Nature Reserve. Proceedings of the Pechora-Ilych State Nature Reserve 1: 5-214. [In Russian] 
Vasilevich M.I., Simakin L.V. 2017. Specifics in the formation of snow cover chemical composition in the Pechora-Ilych Biosphere Reserve area. Geoecology, Engineering Geology, Hydrogeology, Geocryology 5: 48-56. [In Russian]

Wardle D.A., Nilsson M.C., Zackrisson O., Gallet C. 2003. Determinants of litter mixing effects in a Swedish boreal forest. Soil Biology and Biochemistry 35(6): 827-835. DOI: 10.1016/S0038-0717(03)00118-4

Willey N., Fawcett K. 2006. A phylogenetic effect on strontium concentrations in angiosperms. Environmental and Experimental Botany 57(3): 258-269. DOI: $10.1016 /$ j.envexpbot.2005.06.005
WRB. 2006. World reference base for soil resources. A Framework for International Classification, Correlation and Communication: World Soil Resources Reports. Rome, Italy. $86 \mathrm{p}$.

Zaidel'man F.R. 2007. The reasons for the formation of light-colored acid eluvial horizons in the soil profile. Eurasian Soil Science 40(10): 1031-1041. DOI: 10.1134/S1064229307100018

Zhangurov E.V., Startsev V.V., Dubrovskiy Y.A., Degteva S.V., Dumov A.A. 2019. Morphogenetic Features of Soils under Mountainous Larch Forests and Woodlands in the Subpolar Urals. Eurasian Soil Science 52(12): 1463-1476. DOI: 10.1134/S1064229319120147

\title{
СРАВНЕНИЕ СТРУКТУРЫ И ХИМИЧЕСКОГО СОСТАВА НАПОЧВЕННОГО ПОКРОВА И ПОЧВ ПИХТО-ЕЛЬНИКОВ ПЕЧОРО-ИЛЫЧСКОГО ЗАПОВЕДНИКА, СЕВЕРНЫЙ УРАЛ
}

\author{
И. Ю. Кудреватых ${ }^{1, *} \mathbb{D}$, А. П. Гераськина ${ }^{2}$ \\ ${ }^{1}$ Институт физико-химических и биологических проблем почвоведения РАН, Россия \\ ${ }^{2}$ Центр по проблемам экологии и продуктивности лесов РАН, Россия \\ *e-mail:averkieva25@rambler.ru
}

Изучены пихто-ельники чернично-зеленомошный (ЧЗ) на подзолах и бореально-высокотравный (БВ) на буроземах в Печоро-Илычском заповеднике, Северный Урал. В каждом типе леса на глубину корнеобитаемой зоны отбирали монолиты размером $50 \times 50 \mathrm{~cm}^{2}(\mathrm{n}=54$ и n $=45$ для БВ и ЧЗ соответственно), из которых выбирали живые растения всех видов трав, кустарничков и мохообразных, определяли их видовую принадлежность и функциональную группу. На тех же участках закладывали почвенные разрезы (три повторности), из каждого горизонта которых отбирали смешанный образец. В образцах растений и почвы измеряли концентрацию $\mathrm{Mg}, \mathrm{Al}, \mathrm{P}, \mathrm{S}, \mathrm{K}, \mathrm{Ca}, \mathrm{Mn}, \mathrm{Fe}$ и $\mathrm{Zn}$ методом рентгено-флуоресцентного анализа. Выявлено, что основу напочвенного покрова изученного БВ пихто-ельника составляют виды высокотравья и по сравнению с флорой ЧЗ в них на 28\% ниже доля бореальных видов, а доля неморальных и нитрофильных видов, наоборот, выше на 20\% и 14\% соответственно. В подземной части растений обоих типов леса накапливается $\mathrm{Mg}, \mathrm{Zn}, \mathrm{Mn}$ и $\mathrm{Al}$, а в надземной - $\mathrm{Ca}, \mathrm{K}, \mathrm{S}, \mathrm{P}$. Различие в химическом составе растений обоих типов леса определяется вариативностью содержания $\mathrm{Ca}, \mathrm{K}, \mathrm{P}$ и $\mathrm{Mg}$, а в высокотравном лесу еще и $\mathrm{Al}, \mathrm{Fe}, \mathrm{Zn}, \mathrm{Mn}$ и $\mathrm{S}$. В ЧЗ пихто-ельнике для бореального мелкотравья характерен более высокий разброс содержания $\mathrm{K}, \mathrm{S}, \mathrm{Mg}, \mathrm{P}, \mathrm{Zn}, \mathrm{Fe}$ и $\mathrm{Al}$, а бореальные кустарнички имели наиболее высокое содержание Mn. В БВ пихто-ельнике луговые травы имели наибольшую вариабельность содержания $\mathrm{P}, \mathrm{S}$, $\mathrm{Al}, \mathrm{Ca}, \mathrm{Fe}$ и $\mathrm{Mn}$, а виды как бореального высокотравья и мелкотравья, так и неморального высокотравья имели сходное содержание $\mathrm{Al}, \mathrm{Fe}, \mathrm{Mn}$ и $\mathrm{Mg}$. При сравнении химического состава почв (горизонты О и А) изученных типов леса выявлено, что в буроземах на 50\% выше содержание $\mathrm{Ca}, \mathrm{Mg}, \mathrm{K}, \mathrm{Zn}, \mathrm{P}$ и $\mathrm{S}$, а в подзолах - $\mathrm{Al}$ и $\mathrm{Fe}$, что определяется, в большей степени, типом подстилающих пород и обильным опадом напочвенного покрова, обогащенным этими химическими элементами.

Ключевые слова: бореально-высокотравные леса, буроземы, подзолы, чернично-зеленомошные леса, эколого-ценотические группы 